\title{
EVALUATION OF TOCOLYTIC ACTIVITY OF AQUEOUS SEED EXTRACT OF SYZYGIUM CUMINI ON OXYTOCIN INDUCED PRETERM LABOR
}

\author{
RAMASAMY M, ANU SEBASTIAN*, ASHLY MERIN GEORGE
}

${ }^{1}$ Department of Pharmacology, P.S.V College of Pharmaceutical Science and Research, Krishnagiri, Tamil Nadu, India. ${ }^{2}$ Department of Pharmacology, Nirmala College of Pharmacy, Muvattupuzha, Kerala, India. ${ }^{3}$ Department of Pharmaceutics, Grace College of Pharmacy, Palakkad, Kerala, India. Email: anusbtn@gmail.com

Received: 11 January 2020, Revised and Accepted: 24 March 2020

ABSTRACT

Introduction: Syzygium cumini is a well-known bioactive plant which has been widely used for the treatment of various diseases in traditional and folk medicine.

Objective: The present investigation was aimed to determine the tocolytic activity of the aqueous seed extract of $S$. cumini (AESC) in animal models.

Methods: The in vitro antioxidant activity of AESC was evaluated by (1, 1-diphenyl-2- picrylhydrazyl ( $\alpha$, $\alpha$-diphenyl- $\beta$-picrylhydrazyl) and (2,2'-azinobis(3- ethylbenzothiazoline-6-sulfonic acid) ABTS radical scavenging assay which showed the hydrogen donating and free radical scavenging activity of extract that aids in the prevention of preterm labor. In vivo tocolytic activity of AESC was evaluated. The level of in vivo antioxidant parameters such as catalase, superoxide dismutase (SOD) and glutathione was restored in the treated group compared to the control group. The AESC was subjected to pharmacological testing in vitro on a piece of isolated rat uterus previously pretreated with estradiol valerate, concentrations used were $80 \mathrm{mg} / \mathrm{ml}$ and $160 \mathrm{mg} / \mathrm{ml}$.

Results: The study showed the promising radical scavenging activity of the extract due to hydrogen-donating ability of the formulation. In the current study, a significant increase in the rate of preterm delivery (PTD) of the control animals was observed when compared with the normal group. The AESC treated group has showed a significant reduction in the rate of PTD which was comparable with the standard treated group as well as the normal group. The study reveals that the extracts have been able to increase the endogenous antioxidant enzyme activities while reducing the lipid peroxidation. The concentrations $(80 \mathrm{mg} / \mathrm{ml})$ and $(160 \mathrm{mg} / \mathrm{ml})$ produce $50.9 \%$ and $70.9 \%$ inhibition, respectively.

Conclusion: The results indicate the presence of active principles in the AESC which may be responsible for the tocolytic activity.

Keywords: Oxidative stress, Preterm labor, Oxytocin, Syzygium cumini.

(C) 2020 The Authors. Published by Innovare Academic Sciences Pvt Ltd. This is an open access article under the CC BY license (http://creativecommons. org/licenses/by/4. 0/) DOI: http://dx.doi.org/10.22159/ajpcr.2020.v13i5.36842

\section{INTRODUCTION}

Plants have been of great importance to mankind due to their medicinal as well as nutritional properties [1]. Plants have been the source of a wide variety of current drugs which are available in the market today. Natural products, commonly termed as "secondary metabolites," are an essential, reputable source of successful drug leads which originate from earth's bio-diverse flora and fauna [2].

The incidence of preterm birth (PTB), or delivery at $<37$ weeks, continues to increase and accounts for $75 \%$ of all neonatal mortality and morbidity. Contractions that do not meet that rate of recurrence or contractions without cervical change several hours after uterine activity starts are called uterine irritability, irregular contractions, Braxton Hicks contractions, or false labor, but have no effect on the cervix are never called preterm labor. To delay or prevent preterm delivery (PTD), true uterine contractions should be detected adequately early (cervical dilatation $<4 \mathrm{~cm}$ ), to allow reasonable success of tocolytic drugs to result in meaningful pregnancy maintenance [3].

\section{Mechanisms of tocolysis}

Myometrial contractility is a complex procedure based on myocytes function. It involves the presence of hormonal receptors, ions channels, intercell gap junctions, and regulatory proteins such as oxytocin, endothelin, tachykinin, and angiotensin. The increase of intracellular calcium concentration is necessary for the uterine smooth muscle contraction.
As shown in Fig. 1, uterine relaxation may be obtained by interfering with an intracellular messenger responsible for contractile proteins effects: $\beta$-adrenergic receptor agonists, nitric oxide (NO) donors, magnesium sulfate, and calcium channel blockers are tocolytic drugs aiming to this. Another pathway involves the inhibition of contracting factors synthesis or its effects. Atosiban, an oxytocin receptor antagonist, and prostaglandin-synthetase inhibitors have this result by interfering with endogenous myometrial stimulators [4].

\section{Oxytocin [5]}

Oxytocin is a hormone that is made in the brain, in the hypothalamus. It is transported to and secreted by, the pituitary gland, which is situated at the base of the brain. In chemistry, oxytocin is classed as a nonapeptide (a peptide containing nine amino acids), while its biological classification is as a neuropeptide. It acts both as a hormone and as a brain neurotransmitter.

The release of oxytocin by the pituitary gland acts to control two female reproductive functions:

- Childbirth

- Breastfeeding.

Rat reproductive system [6]

The female reproductive system consists of the two ovaries and the female genital tract. The genital tract includes the oviducts, uterus, cervix, and vagina. The female genital tract in mammals arises from the 
mullerian ducts, commencing with the ostium of the oviduct. In the rat, this ostium forms a complete capsule called the ovarian bursa, which envelop the ovary. The oviducts are small, extremely coiled tubes. The uterus consists of two separated uterine horns, enabling the rat to have multiple offspring. The vagina of the rat opens directly to the exterior.

\section{Estrous cycle}

The rat estrous cycle is short, lasting 4-5 days. It occurs throughout the year, with no seasonal effect. The first regular estrous cycle occurs about 1 week after the opening of the vaginal orifice, usually 33-42 days after birth. The cycle length increases slightly with age and past about 6 days near the ending of the reproductive life span.

The estrous cycle in the rat consists of four stages known as proestrus, estrus, metestrus, and diestrus. Proestrus lasts approximately $12 \mathrm{~h}$; estrus, 9-15 h; metestrus, $21 \mathrm{~h}$; and diestrus (the longest phase), over 57 h Fig. 2.

\section{Oxidative stress}

Oxidative stress is an imbalance between free radical production and antioxidant defenses and is associated with damage to a wide range of molecular species including lipids, proteins, and nucleic acids. Shortterm oxidative stress may occur in tissues injured by trauma, infection, heat injury, hypertoxia, toxins, and excessive exercise. These injured tissues produce increased radical generating enzymes (e.g., xanthine oxidase, lipoxygenase, and cyclooxygenase) activation of phagocytes, release of iron, copper ion, or a disruption of the electron transport chains of oxidative phosphorylation producing excess reactive oxygen species (ROS) [7].

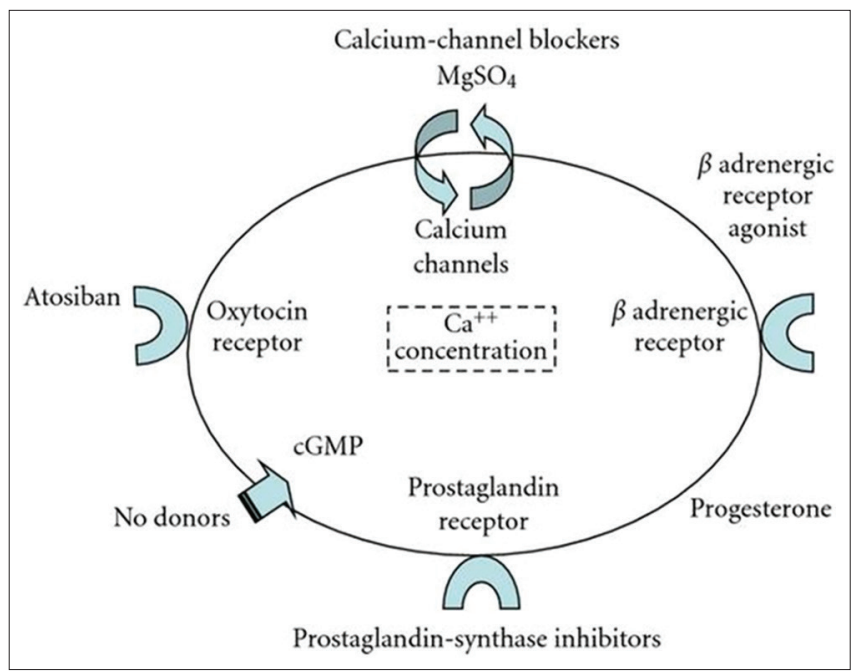

Fig. 1: Mechanisms of action for tocolytics

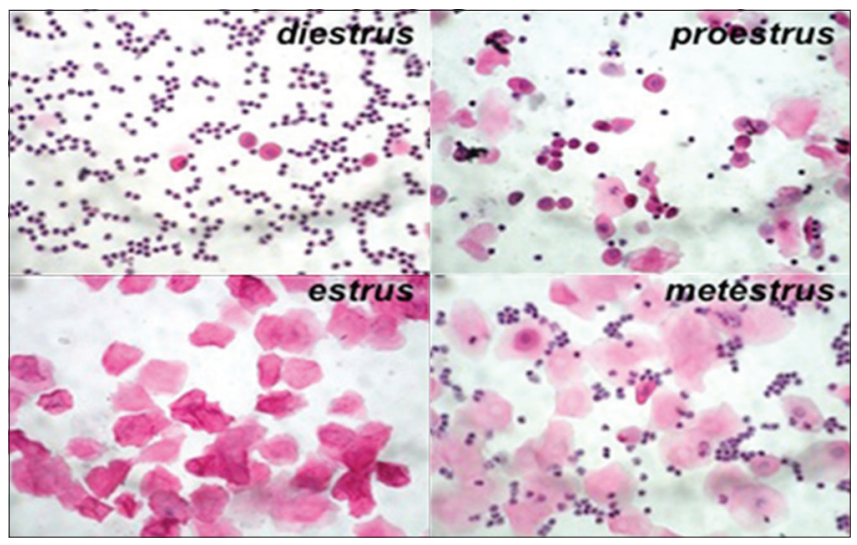

Fig. 2: Diagram showing stages of estrus cycle in rats

\section{Enzymatic antioxidant defenses}

Antioxidant enzymes participate in a complex interaction of reducing and oxidizing molecules that defines the cellular milieu necessary for maintaining cellular, placental, fetal, and postnatal growth. Such enzymes have small activity in preterm infants and cannot balance excessive ROS production. The most significant antioxidant enzymes are copper-zinc superoxide dismutase (SOD), which are found in cytoplasm as well as peroxisomes, and manganese SOD from mitochondria. SOD catalyzes the dismutation of superoxide anion to $\mathrm{H}_{2} \mathrm{O}_{2}$. Glutathione peroxidase $(\mathrm{GPx})$ in mitochondria and catalase (CAT) in peroxisomes catalyze the reaction of $\mathrm{H}_{2} \mathrm{O}_{2}$ to molecular oxygen and water. These enzymes, together with Vitamin E, play an important role in the peroxidation of polyunsaturated free fatty acids in cell membrane [8].

Syzygium cumini L. family Myrtaceae is a well-known common fruit in India. The seed is used in various alternative healing systems such as Ayurveda, Unani, and Chinese medicine for digestive ailments. The literature study done so far revealed that there is a lack of scientific data concerning the tocolytic evaluation of the $S$. cumini seed extract on animal models

The aim of the current study is to assess the tocolytic effect of the aqueous seed extract of $S$. cumini (AESC) on oxytocin induced preterm labor.

The objectives of the present study include:

- Evaluation of in vitro antioxidant activity of the S. cumini seed extract

- Tocolytic activity of $S$. cumini seed extract

- Evaluation of in vivo antioxidant activity of the S. cumini seed extract

- Studies on isolated rat uterus.

The present study examines the efficacy of AESC as a tocolytic agent. The effect of the drug was evaluated on female Wistar rats.

1. Review of literatures

2. Selection, collection, and authentication of plant material

3. Extraction of dried seeds with water

4. Preliminary phytochemical analysis

5. Quantification of total phenol and flavonoid content

6. In vitro antioxidant study

- $\quad(1,1$-diphenyl-2- picrylhydrazyl ( $\alpha, \alpha$-diphenyl- $\beta$ picrylhydrazyl) (DPPH) radical scavenging assay

- $\quad$ ABTS radical cation assay.

7. Tocolytic activity

8. In vivo antioxidant study

- $\quad$ Enzymatic antioxidants (SOD, CAT)

- $\quad$ Non-enzymatic antioxidant (GSH)

- $\quad$ Estimation of Lipid Peroxidation (LPO)

9. Study on isolated rat uterus tissue

10. Statistical analysis of the results.

\section{METHODS}

\section{Pharmacognostic studies}

Collection of plant material and authentication

The plant material was collected and authenticated by Dr. K. Madhava Chetty. Ph. D., Assistant Professor, Department of Botany, Sri Venkateswara University, Tirupati, Andhra Pradesh. The seeds were processed, powdered coarsely and coarse seeds were used for extraction.

\section{Extraction of the seeds [9]}

The dried seeds were coarsely powdered. The powdered seeds (200 g) were taken in a round bottom flask and were extracted with water for $48 \mathrm{~h}$ at room temperature. After $48 \mathrm{~h}$, the extract was concentrated in a rotary evaporator.

\section{Preliminary phytochemical analysis of the extract}

The information about the constituents present in the plant clarifies the medicinal uses of the plant. Identification and evaluation of herbal 
extracts are a fundamental procedure and parts of quality control protocol. The aqueous extract of $S$. cumini seed was subjected to phytochemical evaluation and identified the various plant constituents present in the test samples by qualitatively and quantitatively. The following studies were carried out in phytochemical analysis.

- Qualitative chemical test

- Estimation of total phenol

- Estimation of total flavonoid.

Qualitative chemical tests

The qualitative chemical tests were carried out for the extract and identified the various secondary metabolites present in the aqueous extract of S. cumini seed.

\section{Preparation of test sample}

$500 \mathrm{mg}$ of the extract was dissolved in $5 \mathrm{ml}$ of distilled water and then filtered. The filtrate was tested to detect the presence of various phytochemical constituents in the sample.

\section{Estimation of total phenol content [10]}

The determinations of total phenol content of the extracts were done by Folin-Ciocalteu (F-C) assay with some modifications. The FolinCiocalteu reagent produces blue color complex when reacted with polyphenol compounds if present in the sample. The assay relies on the transfer of reducing electrons in the alkaline medium, from phenolic compounds to phosphomolybdic acid complexes, manifested in the formation of blue color that is estimated by ultraviolet-visible spectrophotometer (Thermo Fischer model Evolution 201).

The extract was prepared as $1 \mathrm{mg} / \mathrm{ml}$ concentration as stock and prepared volume of $1 \mathrm{ml}$ of each sample was taken in $2 \mathrm{ml}$ centrifuge tube followed by $0.5 \mathrm{ml} \mathrm{F-C} \mathrm{reagents} \mathrm{(1:10} \mathrm{diluted} \mathrm{with} \mathrm{distilled} \mathrm{water)}$ were added and allowed to react for $5 \mathrm{~min}$ before adding $0.4 \mathrm{ml} \mathrm{20 \%}$ $\mathrm{Na}_{2} \mathrm{CO}_{3}$. The above solutions were mixed and allowed to stand $15 \mathrm{~min}$ at room temperature then measured absorbance of sample at $765 \mathrm{~nm}$. The blank was prepared in similar manner without sample and standard. Calibration curve was plotted using gallic acid as standard (10, 20, 40, 60,80 , and $100 \mu \mathrm{g} / \mathrm{ml}$ ).The results were expressed as milligram of gallic acid equivalents per gram of extract Fig. 3 .

\section{Estimation of total flavonoid content [11]}

Total flavonoid content was estimated for all the extracts by aluminum chloride colorimetric assay with some modifications. $1 \mathrm{ml}$ aliquot of appropriately diluted sample or standard solution of quercetin $(10,20$, $40,60,80$, and $100 \mu \mathrm{g} / \mathrm{ml}$ ) was mixed with $50 \mu \mathrm{L}$ of $\mathrm{NaNO}_{2}$ in $2 \mathrm{ml}$ micro centrifuge tube. After $6 \mathrm{~min}, 50 \mu \mathrm{L}$ of a $10 \%$ aluminum chloride solution was added and allowed to stand for $6 \mathrm{~min}$, and then $50 \mu \mathrm{l} 1 \mathrm{M}$ potassium acetate solution was added to the mixture. The final volume was made up with distilled water to $2 \mathrm{ml}$, and then the mixture was thoroughly mixed and allowed to stand for another $15 \mathrm{~min}$. The absorbance of the mixture was determined at $510 \mathrm{~nm}$ against prepared blank. The blank was prepared in the same above manner omitting sample and standard. All values were expressed as milligrams of quercetin equivalent per $1 \mathrm{~g}$ of sample Fig. 4.

\section{In vitro antioxidant study}

Various methods are used to investigate the antioxidant property of samples. In the present study, the antioxidant properties of the extract were evaluated by in vitro methods.

The antioxidant properties could not be concluded based on the single antioxidant test method. It is in practice that generally several in vitro test procedures are carried out to conclude the antioxidant properties of the sample. Among various free radical scavenging methods DPPH and ABTS assays were carried out in the present study.

\section{DPPH radical scavenging activity}

The DPPH assay method is based on the reduction of DPPH, a stable free radical. The free radical DPPH with an odd electron gives a maximum absorption at $517 \mathrm{~nm}$ (purple color).

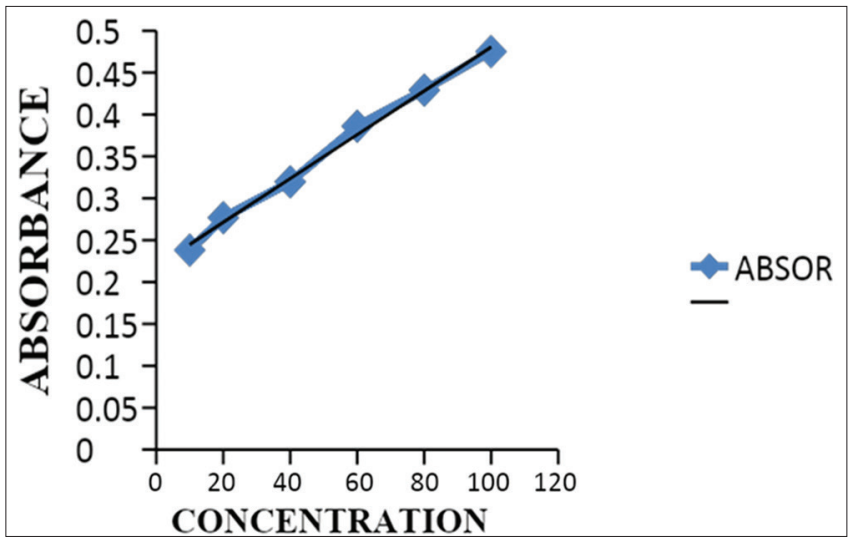

Fig. 3: Standard graph for gallic acid for the estimation of total phenolic content

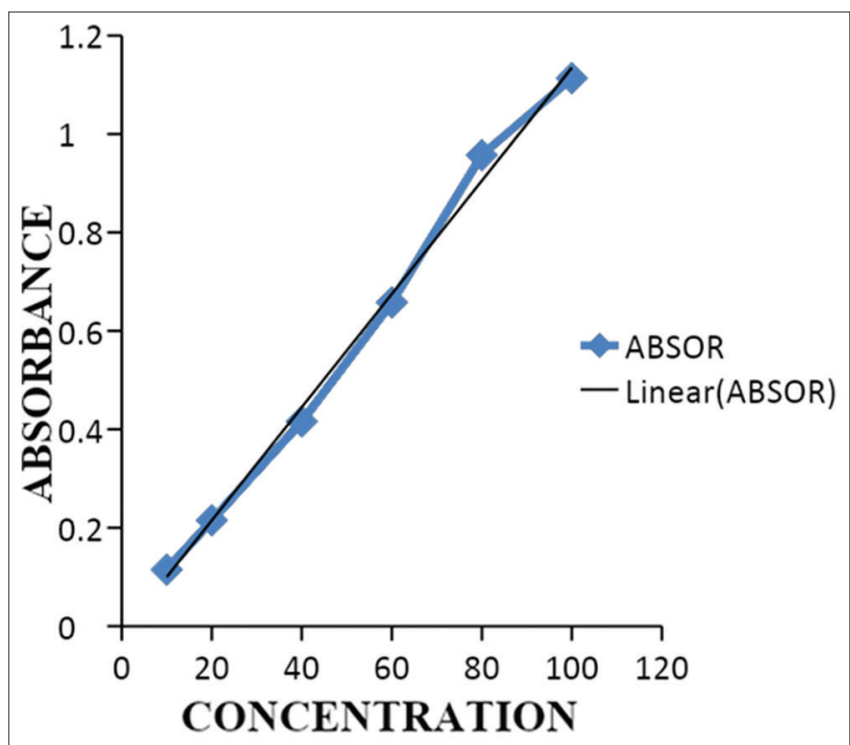

Fig. 4: Standard graph of quercetin for the estimation of total flavonoid content

\section{Procedure}

$0.3 \mathrm{mM}$ solution of DPPH in methanol was prepared and $1 \mathrm{ml}$ of this solution was added to $1 \mathrm{ml}$ of various concentrations of sample $(10,20$, $40,60,80$, and $100 \mu \mathrm{g} / \mathrm{ml})$ and the reference compound $(5,10,15,20$, 25 , and $30 \mu \mathrm{g} / \mathrm{ml}$ ) was shaken vigorously and left to stand in the dark at room temperature for $30 \mathrm{~min}$ and then absorbance was measured at $517 \mathrm{~nm}$. A control reaction was carried out without the test sample. Quercetin was used as standard and all the tests were performed in triplicate to get the mean values. The percentage of inhibition was calculated by comparing the absorbance values of the control and test samples. Antiradical activity was expressed as inhibition percentage (I \%) and calculation using the following equation:

$$
\text { Percentage inhibition }(\mathrm{I} \%)=\left\{\left(\mathrm{Abs}_{\text {control }}-\mathrm{Abs}_{\text {sample }}\right) \div \mathrm{Abs}_{\text {control }}\right\} \times 100
$$

The different sample concentrations were used to obtain calibration curves and to calculate the $\mathrm{EC}_{50}$ values $\left(\mathrm{EC}_{50}\right.$ : Concentration required to obtain a $50 \%$ radical scavenging activity). The $\mathrm{IC}_{50}$ value was defined as the concentration (in $\mu \mathrm{g} / \mathrm{ml}$ ) of extracts that inhibits the formation of DPPH radicals by $50 \%$.

ABTS radical cation scavenging activity

ABTS radical scavenging activity of the extract was measured by RiceEvans method. ABTS was dissolved in water to a $7 \mathrm{mM}$ concentration. ABTS 
radical cation $(\mathrm{ABTS}+)$ was produced by reacting ABTS stock solution with $2.45 \mathrm{mM}$ potassium persulfate and allowing the mixture to stand in the dark at room temperature for $12-16 \mathrm{~h}$ before use. The radical was stable in this form for more than 2 days when stored in the dark at room temperature. For the study, ABTS solution was diluted with phosphate buffer saline $\mathrm{pH} 7.4$ to an absorbance of $0.70( \pm 0.02)$ at $734 \mathrm{~nm}$ and equilibrated at $300^{\circ} \mathrm{C}$. After addition of $1 \mathrm{ml}$ of diluted ABTS solution to various concentrations of sample $(5,10,15,20,25$, and $30 \mu \mathrm{g} / \mathrm{ml})$ or reference compound $(0.25,0.5$, $0.75,1,1.25$, and $1.5 \mu \mathrm{g} / \mathrm{ml}$ ), the reaction mixture was incubated for $6 \mathrm{~min}$ and then absorbance was measured at $734 \mathrm{~nm}$ against a blank. A control reaction was carried out without the sample. All the tests were performed in triplicate to get the mean values. The percentage inhibition of ABTS+ by the sample was calculated according to the formula.

$$
\text { Percentage inhibition }(\mathrm{I} \%)=\left(\mathrm{Abs}_{\text {control }}-\mathrm{Abs}_{\text {sample }} / \mathrm{Abs}_{\text {control }}\right) \times 100
$$

The different sample concentrations were used to obtain calibration curves and to calculate the $\mathrm{IC}_{50}$ values $\left(\mathrm{IC}_{50}\right.$ - concentration required to obtain a $50 \%$ radical scavenging activity).

\section{Pharmacological study}

Animals and diet

Female Wistar rats, weighing 150-200 g, were obtained from KMCH College of Pharmacy, Coimbatore. The animals were housed under controlled conditions of temperature $\left(20-25^{\circ} \mathrm{C}\right)$ and photoperiod $12-\mathrm{h}$ light/dark cycle.

All the rats were fed a pelletized commercial chow diet and fresh water ad libitum throughout the experimental period, and weight gain measured weekly.

All animal procedures were performed after approval from the ethics committee and accordance with the recommendations for the proper care and use of laboratory animals.

\section{Tocolytic activity}

Experimental design

Thirty female Wistar albino rats of 150-200 g were used for the study. The rats were divided into five groups of six animals each.

Procedure

The rats were divided into five groups of six animals each. The Group I was treated with normal saline, Group II was treated with oxytocin (1 IU i.m) only, Group III was treated with atosiban ( $6 \mathrm{mg} / \mathrm{kg}$ ), i.p, and Group IV and Group V were treated with 200 and $400 \mathrm{mg} / \mathrm{kg}$ of AESC, respectively Table 1 .

\section{MATING OF RATS}

\section{Requirements for obtaining vaginal smear:}

Normal saline: The dropper needs only a small volume of normal saline $(0.2-0.25 \mathrm{ml})$ for flushing. Distilled water can also be used without markedly distorting the cells enough to impair identification. Only a drop or two needs to be placed on a slide.

Slides: Microscopic slides can be used.

Microscope: A standard laboratory compound microscope is perfectly sufficient to evaluate a vaginal smear.

Stain: $0.1 \%$ methylene blue.

\section{Table 1: Experimental design for oxytocin induced preterm} labor

\begin{tabular}{ll}
\hline Groups & Treatment \\
\hline Group I & Normal saline \\
Group II & Oxytocin $(1 \mathrm{IU}), \mathrm{i} . \mathrm{m}$ \\
Group III & Atosiban $(6 \mathrm{mg} / \mathrm{kg})$, i.p \\
Group IV & AESC $(200 \mathrm{mg} / \mathrm{kg})$, p.o \\
Group V & AESC $(400 \mathrm{mg} / \mathrm{kg})$, p.o \\
\hline
\end{tabular}

\section{Procedure}

The thirty (30) female rats were randomly distributed into 10 cages such that each cage contained 3 female rats. Each of the rats was identified with an indelible marker. After the distribution and identification of the female rats, a vaginal smear of each of them was made on a labelled clean glass slide.

The smear was collected by carefully with droppers, although moistened cotton swabs have also been used. Dropper tips should be smooth and tapered. If a single dropper is used for more than one animal, it should be thoroughly rinsed between lavages to remove any residual cells from the dropper wall. When inserting the tip of the dropper into the vaginal orifice, it is important that the penetration be relatively shallow, approximately $1 \mathrm{~cm}$.

Immediately after withdrawal from the vaginal cavity, the content was smeared onto a labelled clean glass slide. The smear was observed grossly to check for the presence of protein coagulates (remnants of the copulatory plug).

After the initial smears were collected from the female rats, the male rats were introduced into 10 cages, such that the male: female ratio in these 10 cages was 1:3. After the introduction of males into the 10 mating cages, vaginal smears were made as described above for each of the females in all the 10 cages daily in the morning, and the smeared slides were observed grossly for protein coagulates. The observation of grossly visible protein coagulates on the vaginal smear of each female was recorded as evidence of mating. The mating was also confirmed by the presence of sperms in the vaginal smear. The sperm was observed by staining the smear with $0.1 \%$ methylene blue shown in Fig 5 .

The presence of sperm in the vaginal smear or observation of a vaginal plug indicates the occurrence of mating. The day that sperm is detected in the vaginal smear is designated as day 1 of gestation. After 10 days of gestation, the fetuses can be palpated, but palpation is more accurate after day 12. By day 13 of gestation, the abdominal enlargement is visible, and mammary development and nipple enlargement can be observed on day 14 of gestation. Once the protein coagulates and sperms were observed on the vaginal smear of each rat, the rat was thereafter weighed at four-day intervals to check the progress of the pregnancy.

\section{In vivo antioxidant activity}

Blood collection

After the end of the treatment period, the animals were anaesthetized with diethyl ether (inhalation) and its blood was collected by retroorbital puncture without adding ethylenediaminetetra acetic acid (EDTA).

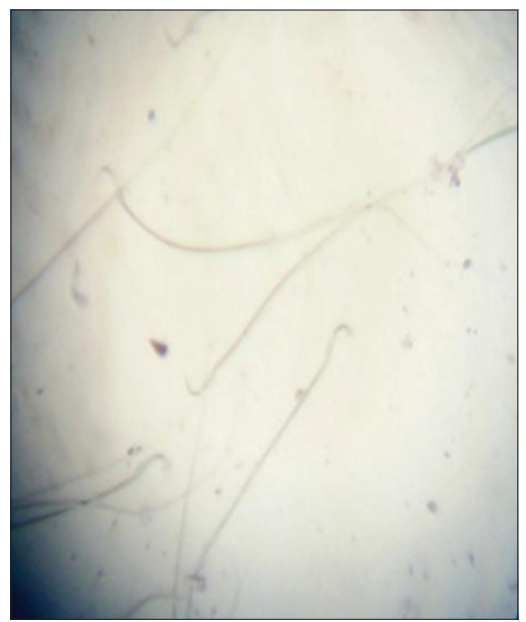

Fig. 5: Microscopical examination $(\times 100)$ vaginal smear of mated animal showing sperms 
Procedure

$0.1 \mathrm{ml}$ sample was made up to $1 \mathrm{ml}$ with distilled water. $5 \mathrm{ml}$ of alkaline solution was added, mixed well and allowed to stand for $10 \mathrm{~min}$. Then, $0.5 \mathrm{ml}$ Folin's reagent was added, mixed well and incubated at room temperature for another $10 \mathrm{~min}$. The blue color developed was measured at $640 \mathrm{~nm}$ against blank. Bovine serum albumin (1 mg/ml) served as the standard and from the standard graph obtained the amount of protein in the sample was calculated.

\section{Enzymatic antioxidant activity}

\section{Estimation of SOD [12]}

To $0.5 \mathrm{ml}$ of the sample, $1.5 \mathrm{ml}$ of carbonate buffer and $0.5 \mathrm{ml}$ of $0.1 \mathrm{mM}$ EDTA were added and mixed. To this, $0.4 \mathrm{ml}$ of adrenaline was added at the time of measurement of the optical density at $480 \mathrm{~nm}$. The antioxidant activity of SOD enzyme was expressed as units $/ \mathrm{min} / \mathrm{mg}$ protein.

\section{Estimation of CAT}

To $1 \mathrm{ml}$ of sample, $4 \mathrm{ml}$ of hydrogen peroxide, and $5 \mathrm{ml}$ of phosphate buffer were added and mixed. From this, $1 \mathrm{ml}$ of solution was taken and mixed with dichromate acetic acid reagent and allowed to incubate for $30 \mathrm{~min}$ at room temperature. The absorbance was measured at $570 \mathrm{~nm}$. The activity of CAT was expressed as $\mu$ mole of $\mathrm{H}_{2} \mathrm{O}_{2}$ consumed $/ \mathrm{min} / \mathrm{mg}$ protein.

\section{Non enzymatic antioxidant activity}

Estimation of reduced GSH activity [13]

To $1 \mathrm{ml}$ of the sample, $1 \mathrm{ml}$ of trichloroacetic acid (TCA) solution was added and centrifuged. The supernatant was collected and the precipitate formed was removed. To $0.5 \mathrm{ml}$ of supernatant, $2 \mathrm{ml}$ DTNB was added, the volume was made up to $3 \mathrm{ml}$ with phosphate buffer. Then, absorbance was read at $412 \mathrm{~nm}$. The amount of GSH was expressed as $\mu \mathrm{g} / \mathrm{mg}$ protein.

\section{Determination of LPO [14]}

To $0.1 \mathrm{ml}$ of sample, $2 \mathrm{ml}$ of TBA-TCA-HCL reagent (ratio of 1:1:1) was added, mixed, and kept in a water bath for $15 \mathrm{~min}$. Afterward, the solution was cooled and supernatant was removed and absorbance was measured at $535 \mathrm{~nm}$ against reference blank. The level of lipid peroxides was given as moles of MDA formed/mg protein.

In vitro study of isolated rat uterus [15]

Female non-pregnant Wistar rats were pre-treated subcutaneously with estradiol valerate $0.1 \mathrm{mg} / \mathrm{kg}$ of $24 \mathrm{~h}$ before the actual experiment for uterine sensitization. The rats were killed by cervical dislocation and exsanguinations. The abdomen was opened and the two horns of the uterus carefully isolated, freed of mesenteric fat, and a strip of the horn about 1-2 cm was cut out. A thread was then attached to one end of the isolated strip of uterus and was tied to the aerator tube in the organ bath containing $25 \mathrm{ml}$ De Jalon's physiological salt solution having the following chemical composition: $\mathrm{NaCl}-9 \mathrm{~g} / \mathrm{L}, \mathrm{NaHCO}_{3}-$ $0.5 \mathrm{~g} / \mathrm{L}$, D-glucose $-0.5 \mathrm{~g} / \mathrm{L}, \mathrm{KCl}-0.402 \mathrm{~g} / \mathrm{L}$, and $\mathrm{CaCl}_{2} \times 2 \mathrm{H}_{2} \mathrm{O}-0.08 \mathrm{~g} / \mathrm{L}$. Another thread was attached to the other end of the isolated uterus and fixed to a lever system. The tissue was aerated and temperature was maintained at $30-32^{\circ} \mathrm{C}$, with a $\mathrm{pH}$ of 7.4 .

The tissue was allowed to equilibrate for $30 \mathrm{~min}$ before the start of the experiment and placed under tension of $0.500 \mathrm{~g}$. A lever system was used to record the uterine contractions and relaxations on a smoked glossy paper in kymograph drum, moved at $2.5 \mathrm{~mm} / \mathrm{s}$ speed which was varnished after and calcul] ated the data. The response of uterine tissue to oxytocin $(0.01 \mathrm{IU} / \mathrm{ml})$ before and after incubation with AESC $(25$ and $50 \mathrm{mg} / \mathrm{ml}$ ) for $1 \mathrm{~min}$ was recorded along with standard drug atosiban (0.5 IU).

\section{Statistical analysis}

The data of all the parameters were analyzed using the GraphPad 5.0 software. Analysis of variance (ANOVA); one-way ANOVA followed by
Tukey comparison test was performed. The values were expressed as Mean \pm SEM.

\section{RESULTS}

\section{Extractive yield}

The percentage yield of AESC: Coarsely powdered seeds of S. cumini were extracted with water and the percentage yield was found to be $14.5 \% \mathrm{w} / \mathrm{w}$

\section{Preliminary phytochemical analysis}

Qualitative chemical tests were conducted and found with positive results.

\section{Quantification of total phenol and flavonoids}

The total phenol content present in AESC was found to be $46.04 \mathrm{mg} / \mathrm{g}$ equivalent to gallic acid and the total flavonoid content in AESC was found to be $47.93 \mathrm{mg} / \mathrm{g}$ of extract calculated as quercetin equivalent.

\section{In vitro antioxidant study}

DPPH radical scavenging activity

The percentage inhibition of DPPH radical by quercetin and AESC was found to be $6.24 \mu \mathrm{g} / \mathrm{ml}$ and $33.15 \mu \mathrm{g} / \mathrm{ml}$, respectively Figs. 6 and 7 .

\section{ABTS radical scavenging activity}

The percentage inhibition of ABTS radical by quercetin and AESC was found to be $0.1895 \mu \mathrm{g} / \mathrm{mL}$ and $4.149 \mu \mathrm{g} / \mathrm{mL}$ Table 2 .

Table 2: Percentage inhibition of ABTS radical by quercetin and AESC

\begin{tabular}{llll}
\hline Sample & $\begin{array}{l}\text { Concentration } \\
(\boldsymbol{\mu g} / \mathbf{m L})\end{array}$ & \% Inhibition & $\mathbf{I C}_{\mathbf{5 0}}(\mu \mathrm{g} / \mathbf{m L})$ \\
\hline Standard & 0.25 & 63.4 & 0.1895 \\
(quercetin) & 0.5 & 67.38 & \\
& 0.75 & 79.79 & \\
& 1 & 87.95 & \\
AESC & 1.25 & 99.41 & \\
& 1.5 & 99.5 & \\
& 5 & 59.79 & \\
& 10 & 69.39 & \\
& 15 & 77.43 & \\
& 20 & 86.53 & \\
& 25 & 98.63 & \\
\hline
\end{tabular}

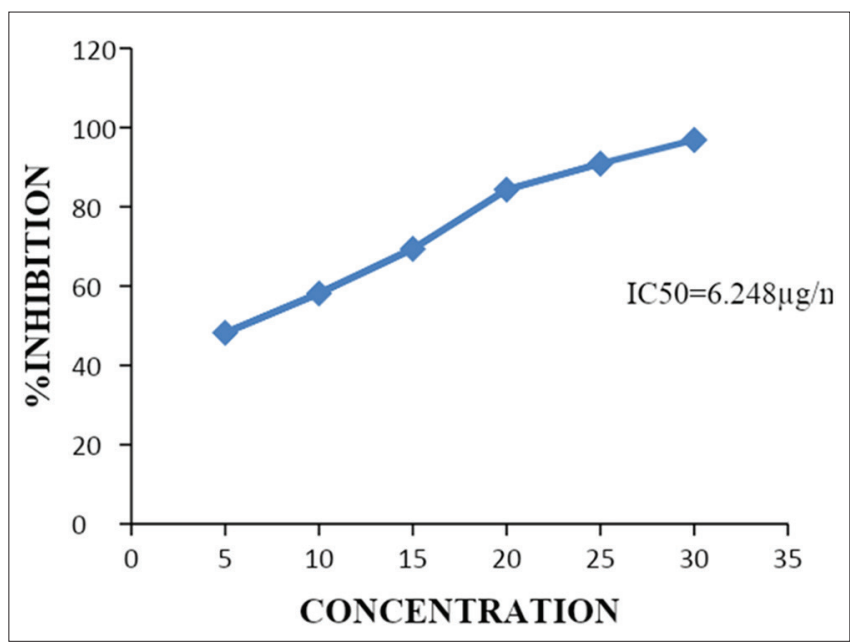

Fig. 6: (1, 1-diphenyl-2- picrylhydrazyl ( $\alpha, \alpha$-diphenyl- $\beta$ picrylhydrazyl) radical scavenging activity of quercetin 
Tocolytic activity

A significant increase in the rate of PTD of the control animals was observed when compared with the normal group. The AESC treated group has showed a significant reduction in the rate of PTD which was comparable with the standard treated group as well as the normal group Table 3 and Fig. 8.

In vivo antioxidant study

The study reveals that the extracts had shown significant in vivo antioxidant activity and the results are expressed in Table 4 and Figs. 9-13.

\section{In vitro study of isolated rat uterus}

The results of in vitro study showed that the aqueous extract of $S$. cumini at $25 \mathrm{mg} / \mathrm{ml}$ and $50 \mathrm{mg} / \mathrm{ml}$ produced significant inhibition of oxytocin, induced contractions of the uterine smooth muscle in non-pregnant rats Fig. 14

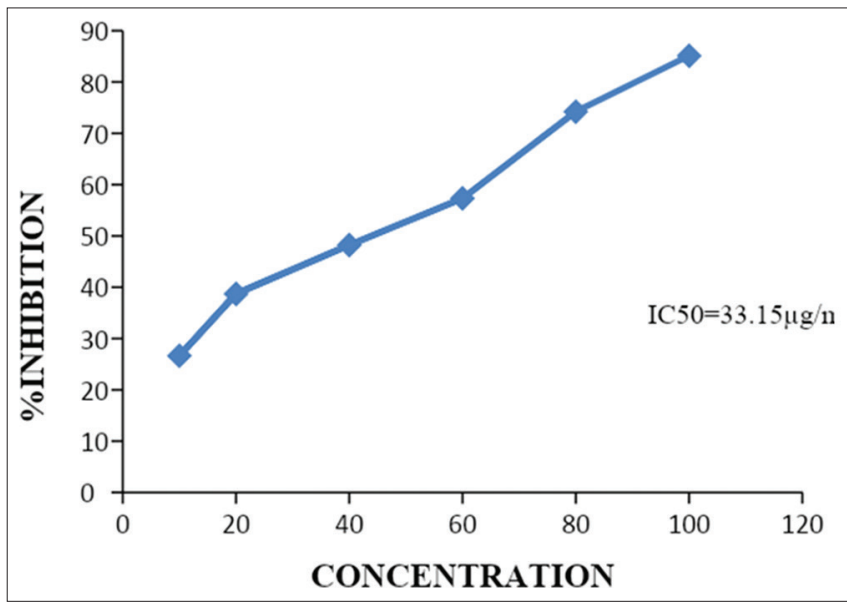

Fig. 7: (1, 1-diphenyl-2- picrylhydrazyl ( $\alpha, \alpha$-diphenyl- $\beta$ picrylhydrazyl) radical scavenging activity of AESC
ANOVA; one-way ANOVA followed by Tukey comparison test was performed. The oxytocin control group was compared with normal and all other groups were compared with oxytocin control group.

ANOVA; one-way ANOVA followed by Tukey comparison test was performed. The oxytocin control group was compared with normal and all other groups were compared with oxytocin control group Table 5.

\section{DISCUSSION}

PTB is the most common cause of neonatal morbidity and mortality worldwide Almost $75 \%$ of perinatal deaths occur in infants born before 37 weeks gestation.

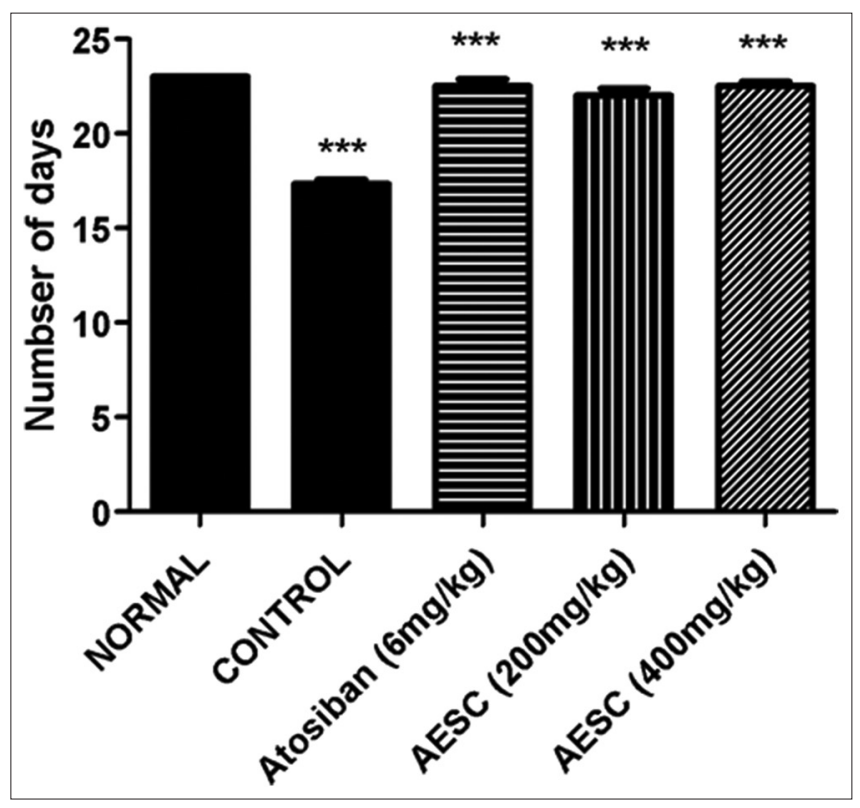

Fig. 8: Effect of AESC on preterm labor

Table 3: Effects of AESC and atosiban on oxytocin induced preterm labor on rat model

\begin{tabular}{|c|c|c|c|c|c|c|c|c|c|}
\hline \multirow[t]{3}{*}{ Drug } & \multirow{3}{*}{$\begin{array}{l}\text { Total number } \\
\text { of rats }\end{array}$} & \multicolumn{6}{|c|}{ Numbers of rat delivered } & \multirow{3}{*}{$\begin{array}{l}\text { Rates } \\
\text { of term } \\
\text { delivery }\end{array}$} & \multirow{3}{*}{$\begin{array}{l}\text { Delivery } \\
\text { day (Mean } \pm \text { SEM) }\end{array}$} \\
\hline & & \multicolumn{4}{|c|}{ Preterm } & \multicolumn{2}{|l|}{ Term } & & \\
\hline & & Day 17 & Day 18 & Day 20 & Day 21 & Day 22 & Day 23 & & \\
\hline Normal & 6 & 0 & 0 & 0 & 0 & 0 & 6 & 100 & $23 \pm 0$ \\
\hline Control (oxytocin 1 IU i.m) & 6 & 4 & 2 & 0 & 0 & 0 & 0 & 0 & $17.3 \pm 0.210^{* * *}$ \\
\hline Control+Atosiban (6 mg/kg, i.p) & 6 & 0 & 0 & 0 & 0 & 3 & 3 & 100 & $22.5 \pm 0.341^{* * *}$ \\
\hline Control+AESC $(200 \mathrm{mg} / \mathrm{kg}, \mathrm{p} .0)$ & 6 & 0 & 0 & 0 & 2 & 2 & 2 & 67 & $22 \pm 0.365^{* * *}$ \\
\hline
\end{tabular}

${ }^{* * *} \mathrm{p}<0.001$. Data are expressed as Mean \pm SEM ( $\mathrm{n}=6$ animals in each group)

Table 4: Effect of AESC on enzymatic and non-enzymatic antioxidant levels

\begin{tabular}{|c|c|c|c|c|c|}
\hline Group & $\begin{array}{l}\text { Total protein } \\
\text { (mg/dl) }\end{array}$ & $\begin{array}{l}\text { SOD } \\
\text { (Unit/mg protein) }\end{array}$ & $\begin{array}{l}\text { CAT } \\
\left(\mu \mathrm{mol} \text { of } \mathrm{H}_{2} \mathrm{O}_{2} \text { consumed/mg protein) }\right.\end{array}$ & $\begin{array}{l}\text { GSH } \\
(\mu \mathrm{g} / \mathrm{mg})\end{array}$ & $\begin{array}{l}\text { LPO } \\
\text { (nmol of MDA/mg protein) }\end{array}$ \\
\hline Normal & $3.9 \pm 0.089$ & $7.4 \pm 0.24$ & $53.3 \pm 0.37$ & $12.8 \pm 0.09$ & $2.8 \pm 0.09$ \\
\hline $\begin{array}{l}\text { Control oxytocin } \\
\text { (1 IU) }\end{array}$ & $9.8 \pm 0.447^{* * *}$ & $2.4 \pm 0.19^{* * *}$ & $28.8 \pm 0.12^{* * *}$ & $6.7 \pm 0.19^{* * *}$ & $8.8 \pm 0.11^{* * *}$ \\
\hline $\begin{array}{l}\text { Control+Atosiban } \\
(6 \mathrm{mg} / \mathrm{kg})\end{array}$ & $2.6 \pm 0.547^{* * *}$ & $6.9 \pm 0.077^{* *}$ & $51.4 \pm 0.43^{* *}$ & $11.9 \pm 0.10^{* * *}$ & $3.7 \pm 0.16^{* *}$ \\
\hline $\begin{array}{l}\text { Control+AESC } \\
(200 \mathrm{mg} / \mathrm{kg})\end{array}$ & $4.8 \pm 0.216^{* *}$ & $4.8 \pm 0.122^{* *}$ & $44.4 \pm 0.4^{* *}$ & $10.88 \pm 0.09 *$ & $6.8 \pm 0.09 * * *$ \\
\hline $\begin{array}{l}\text { Control+AESC } \\
(400 \mathrm{mg} / \mathrm{kg})\end{array}$ & $3.9 \pm 0.044^{* * *}$ & $5.8 \pm 0.13^{* * *}$ & $48.8 \pm 0.09^{* * *}$ & $11.8 \pm 0.122^{* * *}$ & $5.9 \pm 0.02^{* *}$ \\
\hline
\end{tabular}

${ }^{* * *} \mathrm{p}<0.001,{ }^{* *} \mathrm{p}<0.01,{ }^{*} \mathrm{p}<0.05$; Data are expressed as Mean \pm SEM; $(\mathrm{n}=6$ animals in each group). SOD: Superoxide dismutase, GSH: Glutathione 


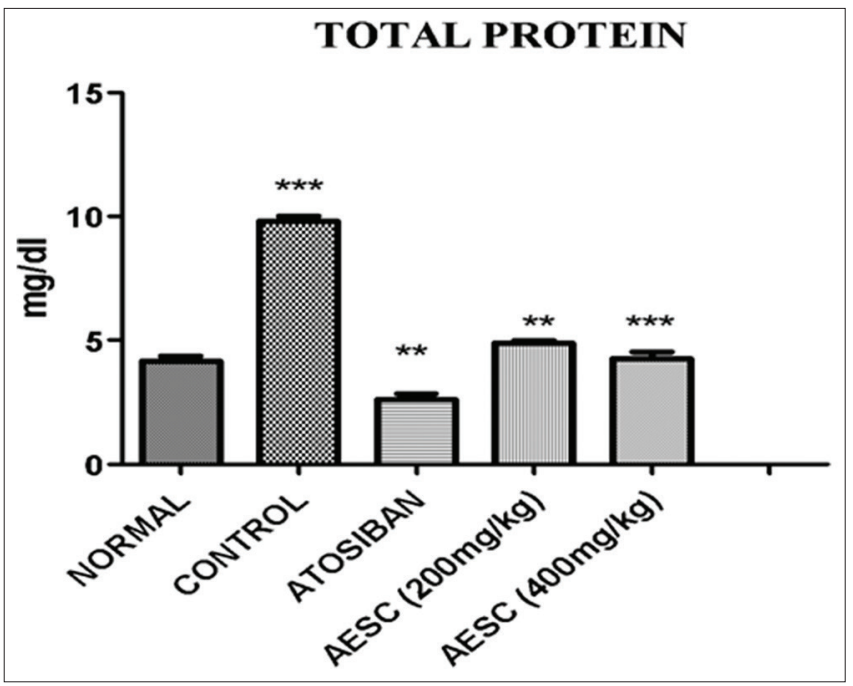

Fig. 9: Effect of AESC on serum total protein

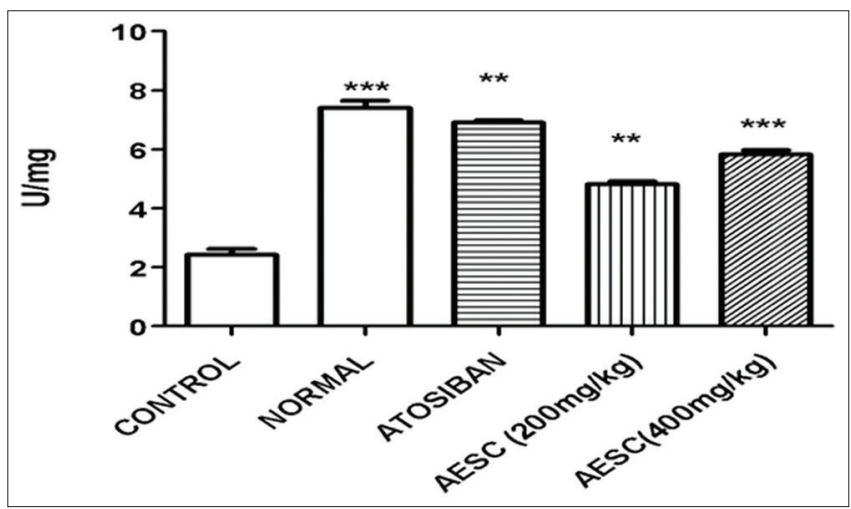

Fig. 10: Effect of AESC on serum superoxide dismutase

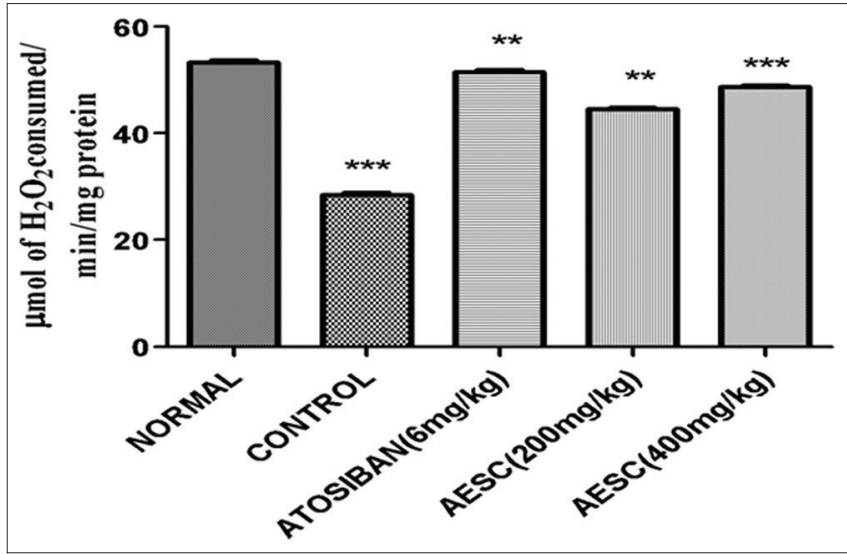

Fig. 11: Effect of AESC on serum CAT
The rationale for treating preterm labor is to reduce perinatal morbidity and mortality by increasing the gestational age at delivery. Assuming tocolysis is beneficial, the choice of drug remains controversial. Magnesium sulfate, calcium channel blockers, prostaglandin synthase inhibitors, NO donors, $\beta$-sympathomimetics, and oxytocin antagonists have all been suggested to be effective. Given the problems of efficacy and adverse effects with each tocolytic, particularly in view of the potentially devastating consequences of PTD, it is not surprising that new drugs have been developed and tested in clinical trials.

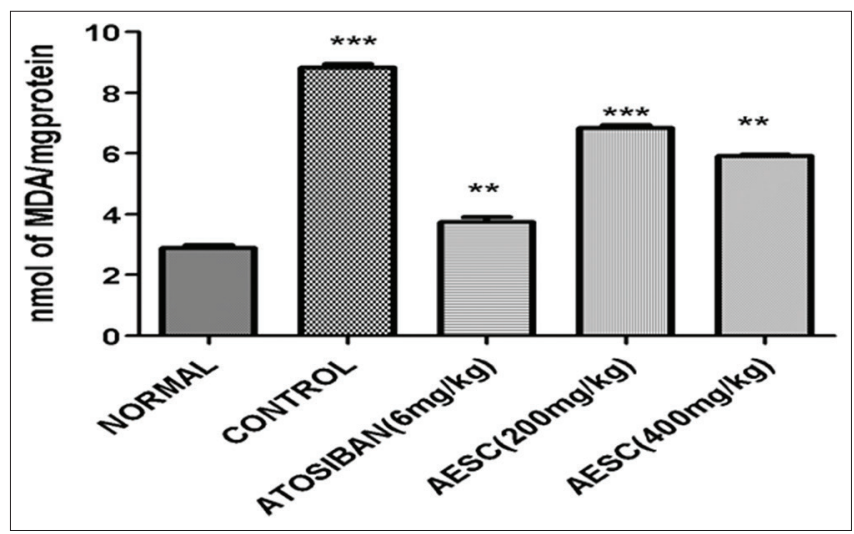

Fig. 12: Effect of AESC on serum lipid peroxidation

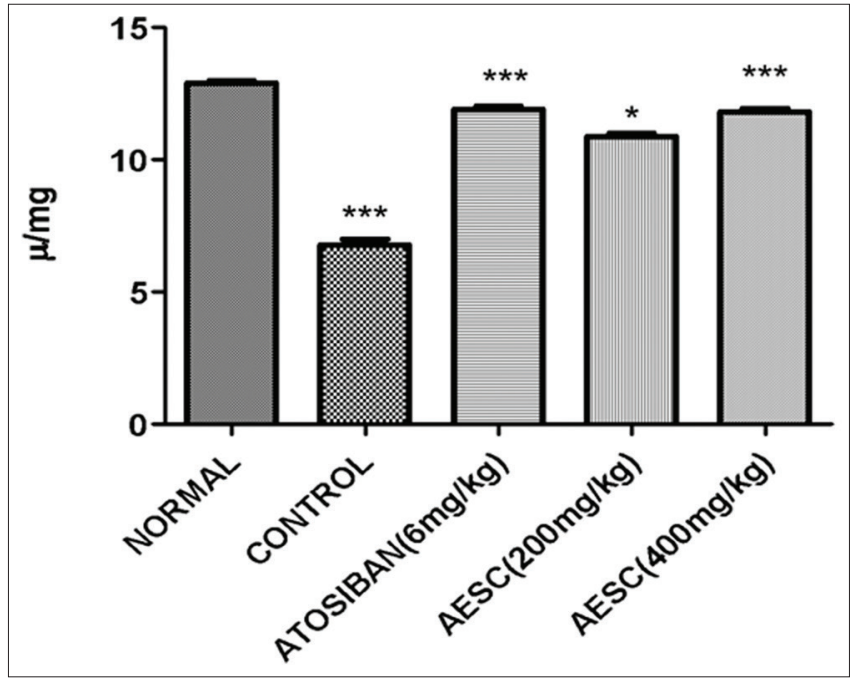

Fig. 13: Effect of AESC on serum glutathione

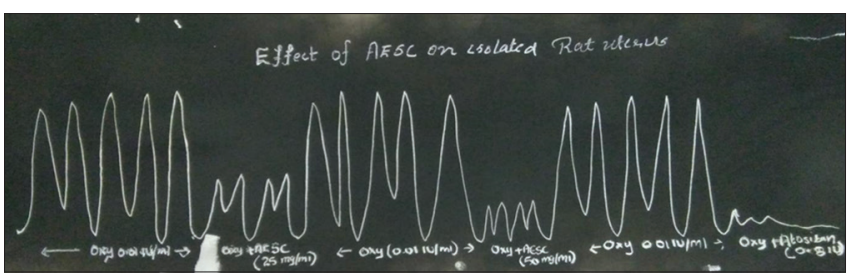

Fig. 14: Effect of AESC and atosiban on isolated rat uterus

Table 5: Effect of AESC on oxytocin induced contraction in rat uterus

\begin{tabular}{lllll}
\hline Group & Drug & Concentration & Height of contractions (cm) & \% Inhibition \\
\hline I & Oxytocin & $0.01 \mathrm{IU} / \mathrm{ml}$ & 5.5 & - \\
II & AESC extract+oxytocin & $25 \mathrm{mg} / \mathrm{ml}+0.01 \mathrm{IU} / \mathrm{ml}$ & 2.7 & 50.9 \\
III & AESC extract+oxytocin & $50 \mathrm{mg} / \mathrm{ml}+0.01 \mathrm{IU} / \mathrm{ml}$ & 1.5 & 72.7 \\
IV & Atosiban+oxytocin & $0.5 \mathrm{IU}+0.01 \mathrm{IU} / \mathrm{ml}$ & 0.57 & 89.6 \\
\hline
\end{tabular}


Phenolics and flavonoid normally scavenge the free radicals and play an essential role in prevention and therapy of PTL, and many more diseases by inducing antioxidant defense system, drug metabolizing enzymes, modulating diverse events in cellular level and inhibiting inflammation, hyperplasia, proliferation, and oxidative DNA damage. Poly phenolic compounds (quercetin, gallic acid, and rutin) are natural antioxidants which decreases oxidation of bio molecules essential for life. The total phenol content present in $S$. cumini seed extract was found to be $46.04 \mathrm{mg} / \mathrm{g}$ equivalent to gallic acid. The total flavonoid content in AESC was found to be $47.93 \mathrm{mg} / \mathrm{g}$ of extract calculated as quercetin equivalent.

Herbal drugs containing radical scavengers are gaining importance in treating oxidative stress related diseases [14]. DPPH radical scavenging activity of the formulation at different concentration was compared with the standard quercetin. Smaller $\mathrm{IC}_{50}$ value indicates a higher antioxidant potential. The higher $\mathrm{IC}_{50}$ values of the sample indicated lesser scavenging activity of the sample when compared with the standard. The study showed the promising radical scavenging activity of the extract due to hydrogen-donating ability of the formulation.

The ability of the formulation to donate hydrogen atoms or electrons to scavenge the radical cation was reflected by the decolorization of ABTS radical cation. The radical scavenging activity of the formulation was compared with that of the standard and the $\mathrm{IC}_{50}$ values obtained were $0.18 \mu \mathrm{g} / \mathrm{ml}$ and $4.14 \mu \mathrm{g} / \mathrm{ml}$ for standard and extract, respectively.

Premature labor still a health challenge worldwide, thus huge efforts were done and required to found a solution for it, this work was an attempt to find a natural solution.

However, the efficacy and safety of tocolytics are not adequate, new agents are therefore required including substances from natural sources [1].

In the current study, a significant increase in the in the rate of PTD of the control animals was observed when compared with the normal group. The AESC treated group has showed a significant reduction in the rate of PTD which was comparable with the standard treated group as well as the normal group.

Living organisms have developed several effective mechanisms to get protection from the ROS. The antioxidant defense mechanisms of the body include enzymes such as SOD, GSH, CAT, and GPx.

In the present study, it was observed that there was a crucial depletion of the activity of all the enzymes and a marked rise of LPO. The study reveals that the extracts have been able to increase the endogenous antioxidant enzyme activities while reducing the LPO.

The cells containing superoxide dismutase enzyme scavenges superoxide ion and prevent its accumulation so that cells are protected from oxidative stress. SOD catalyses this dismutation of superoxide in which one $\mathrm{O}_{2}{ }_{2}$ is oxidized to $\mathrm{O}_{2}$ while the other is reduced to $\mathrm{H}_{2} \mathrm{O}_{2}$. The formed $\mathrm{H}_{2} \mathrm{O}_{2}$ is able to damage the cellular components and is instantly removed by enzymes such as CAT and GPx. A significant decrease in SOD levels was observed in control (oxytocin) rats when compared to normal rats. The levels get increased in the rats treated with both low dose $(200 \mathrm{mg} / \mathrm{kg})$ and high dose $(400 \mathrm{mg} / \mathrm{kg})$ of AESC when compared to SOD levels in control rats.

Oxidative stress has a major role in preterm labor. The CAT enzyme is an endogenous antioxidant enzyme that neutralizes ROS by converting $\mathrm{H}_{2} \mathrm{O}_{2}$ into $\mathrm{H}_{2} \mathrm{O}$ and $\mathrm{O}_{2}$. Among the other antioxidant enzymes, including SOD and GPX, CAT is an elementary defense against oxidative stress. In oxytocin control rats, a significant decreased level of CAT was observed as compared to normal rats. The low dose $(200 \mathrm{mg} / \mathrm{kg})$ and high dose ( $400 \mathrm{mg} / \mathrm{kg}$ ) of AESC treated groups showed significant increase in CAT levels when compared to control rats.
Reduced GSH prevents free radical induced oxidation of sulfhydryl (SH) groups of various proteins to disulfide derivatives. It also protects hemoglobin from getting oxidized by $\mathrm{H}_{2} \mathrm{O}_{2}$. A significant decrease in the GSH levels was observed in the control rats when compared to normal control rats. Rats treated with both low dose $(200 \mathrm{mg} / \mathrm{kg})$ and high dose $(400 \mathrm{mg} / \mathrm{kg})$ of AESC showed significantly higher GSH levels when compared to control rats.

LPO indicates the oxidative degradation of lipids in which the free radicals steals electrons from the lipids in the cell membrane and leads to cell damage. This process proceeds by a free radical chain reaction mechanism. Radical reaction consists of initiation, propagation, and termination processes. A significant increased level of LPO was observed in the control rats when compared to normal control rats. The low dose $(200 \mathrm{mg} / \mathrm{kg})$ and high dose $(400 \mathrm{mg} / \mathrm{kg})$ of AESC treated rats showed significant decreased LPO levels when compared to control rats.

The uterus is spontaneously active, which means that, with or without any nervous/hormonal stimulation, a piece of isolated, pregnant, or non-pregnant, uterus will produce regular spontaneous contractions [16].

The results of in vitro study showed that the aqueous extract of S. cumini at $25 \mathrm{mg} / \mathrm{ml}$ and $50 \mathrm{mg} / \mathrm{ml}$ produced significant inhibition of oxytocin, induced contractions of the uterine smooth muscle in non-pregnant rats.

It is envisaged that the active ingredients (compounds) will have a potential for being added to the present list of tocolytic agents used clinically. To improve the safety of this traditional herbal remedy, additional research is needed to define the stability and bioactivity of this product. Therefore, further studies are needed for the isolation and characterization of the active constituents.

\section{CONCLUSION}

S. cumini Linn (family Myrtaceae) is a well-known bioactive plant in Ayurvedic system of medicine. The present investigation was aimed at determining the tocolytic activity of AESC.

AESC showed significant in vitro antioxidant activity by terminating the actions of free radicals. The extract was studied for its tocolytic activity using oxytocin induced preterm labor in which atosiban $(6 \mathrm{mg} / \mathrm{kg})$ was used as the standard.

The study revealed that the aqueous extract of $S$. cumini seed possesses significant tocolytic activity which was evident with reduction in the incidence of PTD.

AESC showed tocolytic activity that is mediated by its effects on rates of PTD, antioxidant (SOD, CAT, GSH, and LPO), and in vitro studies. The aqueous extract of $S$. cumini possesses tocolytic activity probably due to the presence of flavonoid. In vitro studies of AESC significantly inhibited the frequency and amplitude of spontaneous uterine contractions on the isolated non-pregnant rat uterus preparations.

Hence, from the present study, it can be concluded that the AESC has the potential to prevent PTD as well as it can reduce the complications of the same. It seems promising that these data obtained from the study can be further validated in the future studies which eventually can be developed as a formulation that offers a high degree of protection from PTD.

\section{AUTHOR CONTRIBUTIONS}

M. Ramasamy: He came with the idea of this research work and contributed his idea throughout the work.

Anu Sebastian: Reviewed many articles, started the work with full confidence and maintained the animals throughout the work. 
Ashly Merin George: Helped in reviewing articles, handled animals with full care.

\section{CONFLICTS OF INTEREST}

No conflicts of interest from authors.

\section{REFERENCES}

1. Adhikari BS, Babu MM, Saklani PL, Rawat GS. Medicinal plants diversity and their conservation status in wildlife institute of India (WII) campus, Dehradun. Ethnobotanical Leafl 2010;14:46-83.

2. Sharma S, Mehta BK. Comparative study of alcoholic and aqueous extracts of Syzygium cumini on carbon tetrachloride-induced hepatotoxicity in Wistar rats. Asian J Pharm Clin Res 2016;9 Suppl 3:1-4.

3. Jaybhaye DL, Varma S, Chaudhary P, Bonde V, Gite A. Tocolytic plant Tectona grandis Linn. Extended study on other systemic effect. J Mahatma Gandhi Inst Med Sci 2016;21:122-9.

4. Kumar SP, Soni K, Saraf MN. The In Vitro tocolytic activity of Sarcostemma brevistigma Wight. Indian J Pharm Sci 2006;68 Suppl 2:190-4.

5. Menon R. Oxidative stress damage as a detrimental factor in preterm birth pathology. Front Immunol 2014;5 Suppl 557:1-14

6. Priya SH, Prakasan N, Purushothaman J. Antioxidant activity, phenolicflavonoid content and high-performance liquid chromatography profiling of three different variants of Syzygium cumini seeds: A comparative study. J Int Ethnopharmacol 2017;6 Suppl 1:112-4.

7. Singh K, Kaur R, Kaur AP. Studies on antioxidant and antimicrobial potential of Syzygium cumini leaves. Res J Pharm Biol Chem Sci 2016;7 Suppl 2:677.

8. Pradhan M. Phytochemistry, pharmacology and novel deliveryapplications of Syzygium cumini (L.). Int J Pharm Pharm Res 2016;7 Suppl 1:659-75.

9. Ratajczak CK, Fay JC, Muglia LJ. Preventing preterm birth: The past limitations and new potential of animal models. Dis Models Mech 2010;3 Suppl 1:407-14.

10. Lakshmanashetty RH, Nagaraj VB, Hiremuth MG, Kumar V. In vitro antioxidant activity of Vitex negundo L. Leaf extract. Chiang Mai J Sci 2010;37 Suppl 3:489-97.

11. Kokate CK. Practical Pharmacognosy. $4^{\text {th }}$ ed. Pune: Pragati Books Pvt. Ltd; 1994. p. 108-9.

12. Yesufu HB, Bassi PU, Khaz IZ, Abdulrahaman FI, Mohammed GT. Phytochemical screening and hepatoprotective properties of aqueous root bark extract of Sarcocephalus latifolius (smith) Bruce (African peach). Arch Clin Microbiol 2010;1 Suppl 2:1-5.

13. Lowry OH, Rosebrough NJ, Farr LA, Randall AJ. Protein measurement with the folin phenol reagent. J Biol Chem 1951;193:265-75.

14. Sun Y, Oberly LW, Li Y. A simple method for clinical assay of superoxide dismutase. Clin Chem 1988;34 Suppl 3:497-500.

15. Sharma S, Mehta BK, Mehta D, Nagar H, Mishra A. A review of pharmacological activity of Syzygium cumuni extracts using different solvent and their effective doses. Int Res J Pharm 2012;3 Suppl 12:54-8.

16. David B, Wolfender JL, Dias DA. The pharmaceutical industry and natural products: Historical status and new trends. Phytochem Rev 2015;14 Suppl 2:299-315. 